\title{
Potent antiatherosclerotic effects of alogliptin in addition to its potent antidiabetic effects
}

This article was published in the following Dove Press journal: Diabetes, Metabolic Syndrome and Obesity:Targets and Therapy 10 May 2012

Number of times this article has been viewed

\section{Shailendra Kapoor \\ Mechanicsville, Richmond, VA, USA}

Correspondence: Shailendra Kapoor 2300 E Cary St Richmond,

VA 23223, USA

$\mathrm{Tel}+\mathrm{I} 8042342345$

Fax + | 804345456 |

Email shailendrakapoor@yahoo.com

\section{To the editor}

I read with great interest the article by Andukuri et al in a recent issue of your journal. ${ }^{1}$ The article makes compelling reading. Interestingly, research over the past few years has shown that in addition to its significant diabetic-modulating effects, alogliptin also exerts significant direct antiatherosclerotic effects.

For instance, alogliptin decreases plasma nonesterified fatty acid levels by $11 \% .{ }^{2}$ It simultaneously has an attenuating effect on serum triglyceride levels, decreasing them by almost $24 \%$. Similarly, Monami et al in a recent meta-analysis reported that alogliptin is associated with a significant attenuation in total serum cholesterol. ${ }^{3}$ Alogliptin also significantly decreases postprandial very low-density lipoprotein and chylomicron levels. ${ }^{4}$ Alogliptin mediates its antiatherosclerotic effects by decreasing expression of interleukin- $1 \beta$ and interleukin- 6 , which is typically enhanced in diabetes. ${ }^{5}$ It also has an attenuating effect on extracellular signal-regulated kinase-mediated expression of metalloproteinases 1 and $12 .{ }^{6}$ This exerts a significant inhibitory effect on macrophagemodulated inflammation and thereby attenuates vascular atherosclerosis.

Interestingly, these hypolipidemic effects of alogliptin are markedly enhanced when used in combination with pioglitazone. For instance, alogliptin with adjunctive pioglitazone therapy decreases plasma nonesterified fatty acid levels by $25 \%-48 \%$ and serum triglyceride levels by $67 \%-77 \% .^{2,7}$ Alogliptin clearly exerts significant antiatherosclerotic and hypolipidemic effects, and may go a long way towards attenuating atherosclerosis-related morbidity and mortality in patients with diabetes as well as the metabolic syndrome.

\section{References}

1. Andukuri R, Drincic A, Rendell M. Alogliptin: a new addition to the class of DPP-4 inhibitors. Diabetes Metab Syndr Obes. 2009;2:117-126.

2. Moritoh Y, Takeuchi K, Asakawa T, Kataoka O, Odaka H. The dipeptidyl peptidase-4 inhibitor alogliptin in combination with pioglitazone improves glycemic control, lipid profiles, and increases pancreatic insulin content in ob/ob mice. Eur J Pharmacol. 2009;602:448-454.

3. Monami M, Lamanna C, Desideri CM, Mannucci E. DPP-4 inhibitors and lipids: systematic review and meta-analysis. Adv Ther. 2012;29:14-25.

4. Eliasson B, Moller-Goede D, Eeg-Olofsson K, et al. Lowering of postprandial lipids in individuals with type 2 diabetes treated with alogliptin and/or pioglitazone: a randomised double-blind placebo-controlled study. Diabetologia. 2012;55:915-925.

5. Ta NN, Schuyler CA, Li Y, Lopes-Virella MF, Huang Y. DPP-4 (CD26) inhibitor alogliptin inhibits atherosclerosis in diabetic apolipoprotein E-deficient mice. J Cardiovasc Pharmacol. 2011;58: $157-166$. 
6. Ta NN, Li Y, Schuyler CA, Lopes-Virella MF, Huang Y. DPP-4 (CD26) inhibitor alogliptin inhibits TLR4-mediated ERK activation and ERKdependent MMP-1 expression by U937 histiocytes. Atherosclerosis. 2010;213:429-435.
7. Moritoh Y, Takeuchi K, Asakawa T, Kataoka O, Odaka H. Combining a dipeptidyl peptidase-4 inhibitor, alogliptin, with pioglitazone improves glycaemic control, lipid profiles and beta-cell function in $\mathrm{db} / \mathrm{db}$ mice. Br J Pharmacol. 2009;157:415-426. 


\section{Author's response}

\section{Marc Rendell}

Division of Endocrinology, Department of Medicine,

Creighton University School

of Medicine, Omaha, NE

\section{Correspondence: Marc Rendell}

Creighton Diabetes Center, 60I North 30th Street, Omaha, NE 68I3I,

USA

$\mathrm{Fax}+$ I 4022805655

Email rendell@asndi.com

The letter by Dr Kapoor points out useful data in animal models. The current long-term cardiac outcome trials of alogliptin will be essential to determine the effect of this agent on the atherosclerotic process in man.

\section{Publish your work in this journal}

Diabetes, Metabolic Syndrome and Obesity: Targets and Therapy is an international, peer-reviewed open-access journal committed to the rapid publication of the latest laboratory and clinical findings in the fields of diabetes, metabolic syndrome and obesity research. Original research, review, case reports, hypothesis formation, expert opinion and commentaries are all considered for publication. The manuscript management system is completely online and includes a very quick and fair peer-review system, which is all easy to use. Visit http://www.dovepress.com/testimonials.php to read real quotes from published authors. 